\title{
Assessment of 0-9897 Seedling Growth and Dry Weight Parameters Under Greenhouse and Field Conditions as Influenced by Seed Source and Seedling Age
}

\author{
Md Mahbubul Islam*, Jannatul Ferdous, Md Marfudul Hoque \\ Bangladesh Jute Research Institute, Dhaka, Bangladesh \\ Email address: \\ mahbub_agronomy@yahoo.com (Md M. Islam) \\ ${ }^{*}$ Corresponding author \\ To cite this article: \\ Md Mahbubul Islam, Jannatul Ferdous, Md Marfudul Hoque. Assessment of O-9897 Seedling Growth and Dry Weight Parameters Under \\ Greenhouse and Field Conditions as Influenced by Seed Source and Seedling Age. American Journal of Plant Biology. \\ Vol. 4, No. 3, 2019, pp. 28-33. doi: 10.11648/j.ajpb.20190403.12
}

Received: September 10, 2019; Accepted: September 27, 2019; Published: October 11, 2019

\begin{abstract}
A series of experiments were conducted to evaluate the plant establishment of white jute seeds collected from five different sources of Bangladesh. The establishment experiments were conducted at greenhouse of BJRI, Dhaka and field of Jute Agriculture Experimental Station (JAES), Manikganj during March to June 2018. The treatments consisted of five different seed sources viz., i) Bangladesh Jute Research Institute (BJRI), ii) Bangladesh Agriculture Development Corporation (BADC), iii), iv) Farmers of two different locations and v) Local market. Farmer's source was divided into two sub-sources. The sub sources were farmer1 of Faridpur and farmer2 of Rangpur locations. Two different conditions were i) Greenhouse and ii) Field. The four seedlings age were 30, 40, 50, and 60 days. The cv. O-9897 of the Corchorus olitorius L. was used as study material. Randomized completely block design with three replication were followed. Results revealed that O-9897 seed's seedling growth and dry weight parametersaffected significantly due to seed sources. The shoot height, base diameter, root length, shoot dry weight and root dry weights for O-9897 seed's influenced significantly due to seed sources in both the condition of greenhouse and field. BJRI and BADC seed sources showed better performance than the others. The attributes showed significant variations for seedling ages in both the conditions also. The highest values were observed in 60 days of seedling age. The interactions of seed sources and seedling ages were highly significant for all the growth and dry weight parameters. The BJRI seeds of 60 days of seedling age performed the highest shoot height, base diameter, and root length, shoot dry weight and root dry weights.
\end{abstract}

Keywords: Corchorus olitorius L., Shoot and Root Length, Base Diameter, Shoot Dry Weight, Root Dry Weight

\section{Introduction}

Jute is one of the mainstays of Bangladesh economy. It plays an important role earning about $5-6 \%$ foreign exchange through exporting jute and jute goods. It covers about $2.86 \%$ of total cropped area. In Bangladesh, annually covering about 0.761 millions ha of land with the production of 1.62 million tons of fibre. The farmers require about 5500 tons of seed to cultivate the said area $[1,2]$. Bangladesh produces world's best quality jute. The agriculture climate of Bangladesh is very much suitable for quality fibre production. As a result supply of quality jute seed will ensure the fibre quality as well as quantity to a great extent. The government of
Bangladesh has given more thrust to promote the jute seed industry by strengthening public sectors dealing with jute seed and also by sensitizing private sectors to reduce the dependence on imported jute seed. The activities of private sectors regarding jute seed are limited on seed import only [3].

Bangladesh requires about 5,000 metric tons of jute seeds of which only $12-15 \%$ is produced and distributed by Bangladesh Agricultural Development Corporation [4]. The rest of seeds is solely produced and utilized by the farmers'. The quality of farmers' seed is not maintained during production, processing and storage. In many cases, farmers' collect their seeds from their friends or neighbors and thus, 
there is no specific system to control the quality of seeds. Hence, it is conceived that the quality of seeds produced by majority of the farmers' is of low standard. Also, there is very little information regarding the level of farmers' knowledge on the production of jute seed and method of quality testing before sowing. Farmers' sometimes get good germination and good crop, but in most cases they get poor germination and a poor crop, and occasionally seeds do not germinate which results in total crop failure [5-7].

The quality status of jute seed at farm level is very poor and farmers' are normally ignorant of seed quality and quality evaluating tests. Farmers' are not aware of the germination percentage, vigor value, pathogens associated with seeds and percentage of moisture in their seeds. Although, there are many researches on the quality of the seed, no effort has yet been made to evaluate the quality of seed at farm level despite $75 \%$ of the total requirements of the jute seed are solely produced and distributed by the farmers'. If it is possible to address and appreciate the seed growers about their seed problems and help understand them to assess quality of jute seeds, they could establish it as a profitable enterprise [8,9]. Seeds from BJRI and BADC of both the jute varieties showed better quality in terms of vigor and pathogen incidence compared to seeds from farmers' and local markets [10].

Jute seed quality does not vary only from farmer to farmer, but also from source-to-source. Information relating to viability, vigour and emergence of jute seed are very scanty under Bangladesh condition. Moreover, the category and extent of jute seed quality throughseedling emergence and establishment of different sources are yet to be elucidated. The present study was, therefore, undertaken to evaluate the performances of seedling growth of white jute and their interactions as influenced by seed sources and seedling age.

\section{Materials and Methods}

The experiments were conducted at the Crop Management Laboratory, Agronomy division of Bangladesh Jute Research Institute (BJRI). The emergence experiment was conducted at Crop Management Laboratory, Agronomy Division of Bangladesh Jute Research Institute (BJRI), Dhaka as Greenhouse and at field of Jute Agriculture Experimental Station, Manikgonj of BJRI during March to June 2017. The treatments consisted of five seed sources viz., i. BJRI, ii. Bangladesh Agricultural Development Corporation (BADC), iii., iv) farmers of two locations and v. local market. The farmers seed source was divided into two sub-sources. The sub sources were farmer1 of Faridpur and farmer2 of Rangpur locations. The seed sample variety O-9897 of Corchorus olitorius L. was used as study material. Primary seed samples of $250 \mathrm{~g}$ each from all sources and from 20 farmers of each location were collected randomly. All the primary seed samples were mixed thoroughly to make a composite sample of each location. From the composite samples $500 \mathrm{~g}$ seeds were taken and was regarded as submitted sample. The submitted seed samples were kept in brown paper bags. All the seed samples collected from the different seed sources were labeled properly and preserved in Gene Bank of BJRI at $20^{\circ} \mathrm{Ctill}$ the samples were used for studies. Working seed samples were taken from the preserved seed samples as per requirement. Total procedure was maintained following the rules [10]. Local market seed samples were collected and processed as that of farmers source of two locations. After collection of seed samples following tests were conducted.

The soil of field opened with power tiller in the month of Mid February, then the land was prepared with the country spade. The Laboratory greenhouse soil was prepared and managed as per recommendation of BJRI. The land was made free from weeds and plant debris by hand collection. During final plot preparation NPK fertilizers were applied in the form of urea, triple super phosphate and muriate of potash. The rates of fertilizers used were $200-50-60-11 \mathrm{~kg}$ of NPKS ha ${ }^{-1}$, respectively. Half quantity of $\mathrm{N}$ and the whole quantity of $\mathrm{P}, \mathrm{K}$ and $\mathrm{S}$ were applied as basal dose. The other half quantity of $\mathrm{N}$ was top dressed in two equal splits at 15 DAS.

Seeds used for the experiments had minimum of $80 \%$ germination. Seeds were sown on 23March and 25 March in greenhouse and in the field, respectively. For each unit plot 500 seeds of each sample sources were sown in broadcast method and later covered with soil. In establishment test, 30 , 40, 50 and 60-day-old seedlings were randomly collected from the greenhouse laboratoryand as well as from field. The data of seedling shoot length, base diameter, root length, shoot dry weight and root dry weightof the seedlings were collected. Treatment mean differences were adjudged by DMRT following level of significance (0.05 and 0.01\%) [12].

\section{Results and Discussion}

Results revealed that at greenhouse, seedling height, base diameter, root length, shoot dry weight and root dry weights differed significantly due to seed sources for the varietyO9897 at greenhouse condition (Table 1). The highest seedling height, base diameter, root length, shoot dry weight and root dry weights $(100.50 \mathrm{~cm}, 10.53 \mathrm{~mm}$ and $12.88 \mathrm{~cm}, 9.88 \mathrm{~g}$ and $2.94 \mathrm{~g}$, respectively) were recorded in BJRI seeds, which were statistically similar to BADC seeds except root length. The lowest seedling height, base diameter and root length were recorded in farmers seed of Faridpur (Table 1). The farmers seed of Faridpur and Rangpur; and market seed had statistically equal seedling height, base diameter, root length, shoot dry weight and root dry weights, the variation was found in seedling height (Table 1).

Irrespective of seed sources seedling height, base diameter, root length, shoot dry weight and root dry weights of O-9897 varied significantly due to different seedling age at field (Table 1). Except root dry weight all others showed statistical similarity in BJRI and BADC seeds. Seedling shoot dry weight and root dry weight were highest in BJRI seeds followed by BADC. The lowest Seedling shoot dry weight of farmers seed of Rangpur, and root dry weight of farmers seed 
of Faridpur; and stem dry weight in farmers seed of Faridpur and root dry weight in market seed were recorded. In terms of seed stem dry weight BADC seed showed statistical similarity with farmers and local market seeds (Table 1). Under field condition significant variations were found in shoot and root dry weight among the seed sources of O-9897 (Table 1). Statistical similarity observed in BJRI and BADC seeds in terms of seedling shoot and root dry weight. The shoot dry weight and root dry weights were highest in BJRI seeds followed by BADC. The lowest shoot and root dry weight were observed in farmers seed of Faridpur. Local market seeds had the third highest shoot and root dry weights among the seed sources. The seedling shoot dry weight of market seed had similarity with BJRI and BADC seeds (Table 1). Development of a normal seedling from the seed is an essential requirement in the maintenance of seed viability. A normal seedling essentially should have a well-developed root system, some intact hypocotyls, two cotyledonary leaves and plumule with developing green leaves Islam, [6], Dempsey, [13].

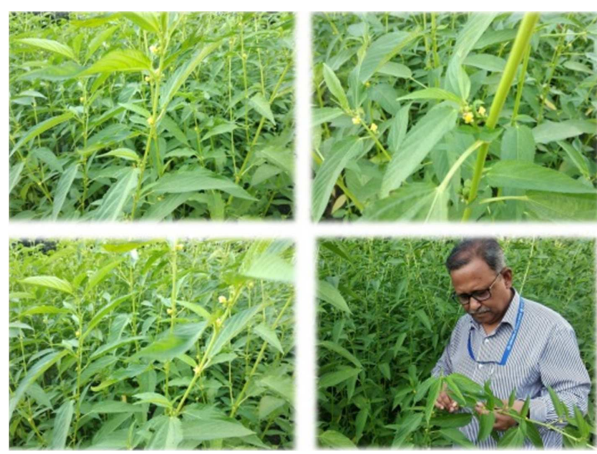

Figure 1. Examining flowering stage on different experimental plots.
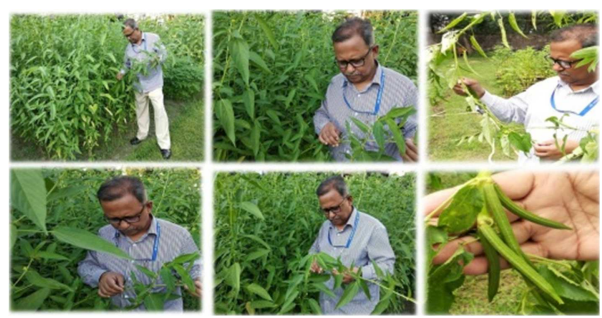

Figure 2. Examining fruiting stage on different experimental plots.

Table 1. Effect of seed sources on seedling growth characters of O-9897 under green houseandfield condition.

\begin{tabular}{|c|c|c|c|c|c|}
\hline \multirow{2}{*}{ Seed sources } & \multicolumn{5}{|l|}{ At greenhouse } \\
\hline & Seedling height $(\mathrm{cm})$ & Base diameter(mm) & Root length(cm) & Shoot dry weight(g) & Root dry weight(g) \\
\hline BJRI & $100.50 \mathrm{a}$ & $10.53 \mathrm{a}$ & $12.88 \mathrm{a}$ & $9.88 \mathrm{a}$ & $2.94 \mathrm{a}$ \\
\hline BADC & $98.42 \mathrm{a}$ & $10.18 \mathrm{a}$ & $12.45 \mathrm{~b}$ & $9.77 \mathrm{a}$ & $2.87 \mathrm{a}$ \\
\hline Farmer1 & $88.33 \mathrm{c}$ & $9.08 \mathrm{c}$ & $10.74 \mathrm{~d}$ & $8.87 \mathrm{~cd}$ & $2.61 \mathrm{c}$ \\
\hline Farmer2 & $90.42 \mathrm{bc}$ & $9.10 \mathrm{bc}$ & $10.88 \mathrm{~cd}$ & $8.94 \mathrm{c}$ & $2.66 \mathrm{bc}$ \\
\hline Local market & $93.42 \mathrm{~b}$ & $9.36 \mathrm{~b}$ & $11.09 \mathrm{c}$ & $9.39 \mathrm{~b}$ & $2.72 \mathrm{~b}$ \\
\hline
\end{tabular}

Table 1. Continued.

\begin{tabular}{lllll}
\hline \multirow{2}{*}{ Seed sources } & At field & & & \\
\cline { 2 - 5 } & Seedling height $(\mathbf{c m})$ & Base diameter(mm) & Root length(cm) & Shoot dry weight(g) \\
\hline BJRI & $82.92 \mathrm{a}$ & $10.29 \mathrm{a}$ & $12.10 \mathrm{a}$ & $9.47 \mathrm{a}$ \\
BADC & $81.17 \mathrm{a}$ & $9.76 \mathrm{~b}$ & $11.61 \mathrm{~b}$ & $9.05 \mathrm{a}$ \\
Farmer1 & $71.83 \mathrm{bc}$ & $8.22 \mathrm{~d}$ & $10.40 \mathrm{c}$ & $8.51 \mathrm{~b}$ \\
Farmer2 & $71.92 \mathrm{c}$ & $8.15 \mathrm{~d}$ & $9.91 \mathrm{~d}$ & $8.40 \mathrm{bc}$ \\
Local market & $74.33 \mathrm{~b}$ & $8.65 \mathrm{c}$ & $10.40 \mathrm{~cd}$ & $9.02 \mathrm{a}$ \\
\hline
\end{tabular}

In a column figures having common letter(s) do not differ significantly by DMRT at $1 \%$ level of probability.

Irrespective of seed sources the seedling age showed significant differences in respect of seedling height, base diameter, root length, seedling shoot and root dry weights at field of the variety O-9897at greenhouse condition (Table 2). The highest seedling heights base diameter and root length were $155.47 \mathrm{~cm}, 15.58 \mathrm{~mm}, 16.24 \mathrm{~cm}, 23.61 \mathrm{~g}$ and $7.60 \mathrm{~g}$, respectively. The lowest were observed at 30 DAS. The seedling height, base diameter and root length increased with the increase of seedling age. Significant differences were observed under seedling age regarding seedling height, base diameter and root length of CVL-1 due to seed sources (Table 2). The highest seedling height, base diameter, root lengths, shoot dry weight and root dry weights were observed at 60 days of seedling age. The lowest seedling height, base diameter and root length were $44.73 \mathrm{~cm}, 4.93 \mathrm{~mm}, 7.02 \mathrm{~cm}$, $1.02 \mathrm{~g}$ and $0.32 \mathrm{~g}$, respectively, were observed at 30 days of seedling age at greenhouse. A chronological increase was found in seedling height, base diameter and root length with the increase of seedling age from 30 to 60 days at an interval of 10 days (Table 2).

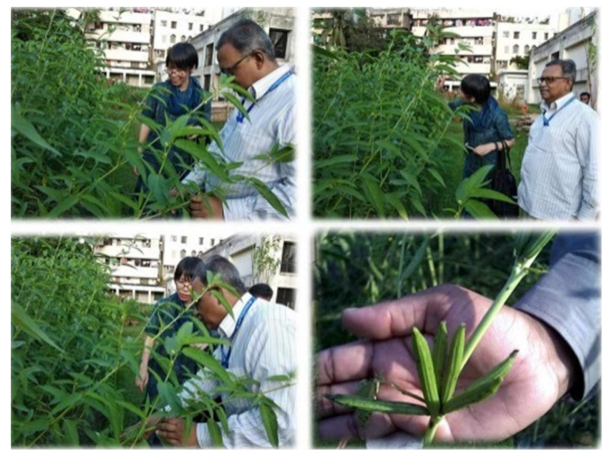

Figure 3. Experimental seed plots demonstration to foreigner.

The highest seedling height, base diameter, root length, 
seedling shoot and root dry weight, were found at 60 days after sowing (DAS) at field. The highest seedling height, base diameter and root length were found in BJRI seeds, which were similar to BADC seeds except base diameter. The farmer's seed of Faridpur had the lowest values for these parameters, which were similar to farmer's seed of Rangpur especially for seedling height at field condition (Table 2). Local market seeds showed a little bit higher performance than farmers seeds. Local market seeds produced similar seedling height as that of farmers' seed of Rangpur (Table 2). Irrespective of seed sources seedling age differed significantly regarding seedling shoot dry weight and root dry weight in O-9897 (Table 2). Gradual increases were found in shoot and root dry weight with the increase of seedling age. In terms of shoot and root dry weight the variations among the seedling age were very high. The highest seedling shoot dry weights were found at 60 days and root dry weights were recorded in both the years at 60 DAS also. The lowest shoot dry weight and root dry weights were found at 30 DAS (Table 2). Seedling age significantly affected the shoot and root dry weights in O-9897 under field condition irrespective of seed sources. Gradual increases were found in seedling shoot and root dry weight with the increase of seedling age. Very high variations among the duration were recorded in shoot and root dry weight at field condition also. The highest SDW of 18.47 Highestighest shoot and root dry weights were observed at 60 DAS, while it was the lowest at 30 DAS (Table 2).

Table 2. Effect of seedling characters of $0-9897$ under greenhouse and field condition.

\begin{tabular}{|c|c|c|c|c|c|}
\hline \multirow{2}{*}{ Seedling age (Days) } & \multicolumn{5}{|l|}{ At greenhouse } \\
\hline & Seedling height $(\mathrm{cm})$ & Base diameter(mm) & Root length(cm) & Shoot dry weight(g) & Root dry weight(g) \\
\hline 30 & $44.73 \mathrm{~d}$ & $4.93 \mathrm{~d}$ & $7.02 \mathrm{~d}$ & $1.02 \mathrm{~d}$ & $0.32 \mathrm{~d}$ \\
\hline 40 & $75.47 \mathrm{c}$ & $7.85 \mathrm{c}$ & $10.61 \mathrm{c}$ & $3.60 \mathrm{c}$ & $1.04 \mathrm{c}$ \\
\hline 60 & $155.47 \mathrm{a}$ & $15.58 \mathrm{a}$ & $16.24 \mathrm{a}$ & $23.61 \mathrm{a}$ & $7.60 \mathrm{a}$ \\
\hline
\end{tabular}

Table 2. Continued.

\begin{tabular}{|c|c|c|c|c|c|}
\hline \multirow{2}{*}{ Seedling age (Days) } & \multicolumn{5}{|l|}{ At field } \\
\hline & Seedling height $(\mathrm{cm})$ & Base diameter(mm) & Root length(cm) & Shoot dry weight(g) & Root dry weight(g) \\
\hline 30 & $37.47 \mathrm{~d}$ & $4.74 \mathrm{~d}$ & $6.72 \mathrm{~d}$ & $1.00 \mathrm{~d}$ & $0.29 \mathrm{~d}$ \\
\hline 40 & $67.53 \mathrm{c}$ & $7.76 \mathrm{c}$ & $9.77 \mathrm{c}$ & $3.05 \mathrm{c}$ & $1.19 \mathrm{c}$ \\
\hline 50 & $85.60 \mathrm{~b}$ & $9.55 \mathrm{~b}$ & $11.99 \mathrm{~b}$ & $8.72 \mathrm{~b}$ & $2.08 \mathrm{~b}$ \\
\hline 60 & $115.13 \mathrm{a}$ & $14.00 \mathrm{a}$ & $15.05 \mathrm{a}$ & $22.78 \mathrm{a}$ & $6.02 \mathrm{a}$ \\
\hline
\end{tabular}

In a column figures having common letter(s) do not differ significantly by DMRT at $1 \%$ level of probability. DAS $=$ days after sowing.

The interaction between seed sources and seedling age affected the seedling height, base diameter, root length, shoot dry weights and root dry weights significantly for O-9897 at greenhouse (Table 3). The highest seedling height, base diameter, root length, shoot dry weight and root dry weights were recorded $(170.00 \mathrm{~cm}, 16.70 \mathrm{~mm}, 17.30 \mathrm{~cm}, 24.40 \mathrm{~g}$ and $8.04 \mathrm{~g}$, respectively) in BJRI seeds at 60 days seedling age. The lowest seedling height and base diameter $(42.32 \mathrm{~cm}$ and $4.07 \mathrm{~mm}$, respectively) were observed in farmers' seed of Faridpur with 30 days seedling age. At 30 days seedling age, was statistically identical to farmers' seed of Faridpur and market seed (Table 3). BADC seeds showed statistically identical results to BJRI. The seedling shoot and root dry weights were the lowest in farmers seed of Faridpur and in local market seed and in farmers seed of Rangpur at 30 DAS. Farmers' seed of both Faridpur and Rangpur; and market seeds showed statistical similarity as regard to seedling age (Table 3).
Seedling height, base diameter, root length, seedling shoot and root dry weights of O-9897 under field condition were significantly affected by the interaction between seed sources and seedling age. The highest seedling height, base diameter, root length, seedling shoot and root dry weights were observed in BJRI seeds at 60 days of seedling age followed by BADC seeds. In farmers seed of Faridpur the lowest values for these parameters were found at 30 DAS. Seedling height, base diameter and root length observed under greenhouse condition were higher than those at the field (Table 3). BADC seeds had statistical similarity with BJRI seed. The seedling shoot and root dry weights were lowest at 30 DAS in farmers seed of Faridpur. Similar root dry weight was observed in farmers' seed of Rangpur. Farmers' seed of both the locations and market seed's had shoot and root dry weights statistically indifferent (Table 3). Results are in agreement with Islam [6] and Islam [10].

Table 3. Interaction effect of seed sources and seedling age on seedling growthcharacters ofO-9897 under green house and field.

\begin{tabular}{|c|c|c|c|c|c|}
\hline \multirow{2}{*}{$\begin{array}{l}\text { Seed sources and seedling } \\
\text { age(days) }\end{array}$} & \multicolumn{5}{|l|}{ At greenhouse } \\
\hline & Seedling height $(\mathrm{cm})$ & Base diameter(mm) & Root length(cm) & Shoot dry wt(g) & Root dry wt(g) \\
\hline \multirow{4}{*}{ BJRI } & $48.00 \mathrm{~d}$ & $6.27 \mathrm{~d}$ & $8.50 \mathrm{~d}$ & $1.06 \mathrm{~d}$ & $0.34 \mathrm{~d}$ \\
\hline & $79.67 \mathrm{c}$ & $8.26 \mathrm{bc}$ & $11.83 \mathrm{bc}$ & $4.02 \mathrm{c}$ & $1.12 \mathrm{c}$ \\
\hline & $104.33 b$ & $10.90 \mathrm{~b}$ & $13.87 \mathrm{~b}$ & $10.04 b$ & $2.24 \mathrm{~b}$ \\
\hline & $170.00 \mathrm{a}$ & $16.70 \mathrm{a}$ & $17.30 \mathrm{a}$ & $24.40 \mathrm{a}$ & $8.04 \mathrm{a}$ \\
\hline
\end{tabular}




\begin{tabular}{lllllll}
\hline \multirow{2}{*}{$\begin{array}{l}\text { Seed sources and seedling } \\
\text { age(days) }\end{array}$} & At greenhouse & & & & \\
\cline { 2 - 7 } & & Seedling height(cm) & Base diameter(mm) & Root length(cm) & Shoot dry wt(g) & Root dry wt(g) \\
\hline \multirow{3}{*}{ BADC } & 30 & $46.33 \mathrm{~d}$ & $5.93 \mathrm{~d}$ & $8.23 \mathrm{~d}$ & $1.04 \mathrm{~d}$ & $0.33 \mathrm{~d}$ \\
& 40 & $77.00 \mathrm{c}$ & $8.03 \mathrm{c}$ & $11.27 \mathrm{c}$ & $3.90 \mathrm{c}$ & $1.08 \mathrm{c}$ \\
& 50 & $102.00 \mathrm{~b}$ & $10.67 \mathrm{~b}$ & $13.40 \mathrm{~b}$ & $10.04 \mathrm{~b}$ & $2.14 \mathrm{~b}$ \\
Farmer1 & 60 & $168.33 \mathrm{a}$ & $16.07 \mathrm{a}$ & $16.90 \mathrm{a}$ & $24.10 \mathrm{a}$ & $7.95 \mathrm{a}$ \\
& 30 & $42.32 \mathrm{~d}$ & $4.07 \mathrm{~d}$ & $6.17 \mathrm{~d}$ & $0.98 \mathrm{~d}$ & $0.29 \mathrm{~d}$ \\
& 40 & $72.65 \mathrm{c}$ & $7.53 \mathrm{c}$ & $9.80 \mathrm{c}$ & $3.22 \mathrm{c}$ & $0.98 \mathrm{c}$ \\
& 50 & $96.65 \mathrm{~b}$ & $9.83 \mathrm{~b}$ & $11.67 \mathrm{~b}$ & $8.27 \mathrm{~b}$ & $1.95 \mathrm{~b}$ \\
Farmer2 & 60 & $141.67 \mathrm{a}$ & $14.90 \mathrm{a}$ & $15.33 \mathrm{a}$ & $23.02 \mathrm{a}$ & $7.20 \mathrm{a}$ \\
& 30 & $43.00 \mathrm{~d}$ & $4.23 \mathrm{~d}$ & $5.90 \mathrm{~d}$ & $1.01 \mathrm{~d}$ & $0.31 \mathrm{~d}$ \\
& 40 & $73.33 \mathrm{c}$ & $7.65 \mathrm{c}$ & $9.97 \mathrm{c}$ & $3.36 \mathrm{c}$ & $0.98 \mathrm{c}$ \\
& 50 & $98.66 \mathrm{~b}$ & $9.83 \mathrm{~b}$ & $11.90 \mathrm{~b}$ & $8.47 \mathrm{~b}$ & $2.04 \mathrm{~b}$ \\
& 60 & $146.67 \mathrm{a}$ & $14.67 \mathrm{a}$ & $15.77 \mathrm{a}$ & $22.91 \mathrm{a}$ & $7.31 \mathrm{a}$ \\
& 30 & $44.00 \mathrm{~d}$ & $4.17 \mathrm{~d}$ & $6.30 \mathrm{~d}$ & $1.03 \mathrm{~d}$ & $0.31 \mathrm{~d}$ \\
& 40 & $74.64 \mathrm{c}$ & $7.73 \mathrm{c}$ & $10.17 \mathrm{c}$ & $3.48 \mathrm{c}$ & $1.02 \mathrm{c}$ \\
& 50 & $104.32 \mathrm{c}$ & $9.97 \mathrm{~b}$ & $12.00 \mathrm{~b}$ & $9.41 \mathrm{~b}$ & $2.04 \mathrm{~b}$ \\
& 60 & $150.66 \mathrm{a}$ & $15.57 \mathrm{a}$ & $15.90 \mathrm{a}$ & $23.63 \mathrm{a}$ & $7.52 \mathrm{a}$ \\
\end{tabular}

Table 3. Continued.

\begin{tabular}{|c|c|c|c|c|c|c|}
\hline \multirow{2}{*}{\multicolumn{2}{|c|}{$\begin{array}{l}\text { Seed sources and seedling } \\
\text { age(days) }\end{array}$}} & \multicolumn{5}{|l|}{ At field } \\
\hline & & Seedling height(cm) & Base diameter(mm) & Root length(cm) & Shoot dry wt(g) & Root dry wt(g) \\
\hline \multirow{4}{*}{ BJRI } & 30 & $40.67 d$ & $5.87 \mathrm{~d}$ & $7.83 \mathrm{~d}$ & $1.08 \mathrm{~d}$ & $0.32 d$ \\
\hline & 40 & $70.67 \mathrm{c}$ & $8.53 \mathrm{bc}$ & $10.87 \mathrm{bc}$ & $3.14 \mathrm{c}$ & $1.30 \mathrm{c}$ \\
\hline & 50 & $90.33 b$ & $10.96 b$ & $12.85 b$ & $9.50 \mathrm{~b}$ & $2.16 \mathrm{~b}$ \\
\hline & 60 & $130.00 \mathrm{a}$ & $15.80 \mathrm{a}$ & $16.83 \mathrm{a}$ & $24.14 \mathrm{a}$ & $6.81 \mathrm{a}$ \\
\hline \multirow{4}{*}{ BADC } & 30 & $38.67 d$ & $5.48 \mathrm{~d}$ & $7.53 \mathrm{~d}$ & $1.04 \mathrm{~d}$ & $0.30 \mathrm{~d}$ \\
\hline & 40 & $69.00 \mathrm{c}$ & $8.07 b c$ & $10.37 \mathrm{bc}$ & $3.08 \mathrm{c}$ & $1.29 \mathrm{c}$ \\
\hline & 50 & $87.33 b$ & $10.37 \mathrm{~b}$ & $12.33 b$ & $9.01 \mathrm{~b}$ & $2.11 \mathrm{~b}$ \\
\hline & 60 & $129.66 \mathrm{a}$ & $15.13 \mathrm{a}$ & $16.20 \mathrm{a}$ & $23.08 \mathrm{a}$ & $6.38 \mathrm{a}$ \\
\hline \multirow{4}{*}{ Farmer1 } & 30 & $35.63 d$ & $3.90 \mathrm{~d}$ & $6.17 \mathrm{~d}$ & $0.96 \mathrm{~d}$ & $0.28 \mathrm{~d}$ \\
\hline & 40 & $66.32 \mathrm{c}$ & $7.40 \mathrm{c}$ & $9.53 \mathrm{c}$ & $2.99 \mathrm{c}$ & $1.10 \mathrm{c}$ \\
\hline & 50 & $80.31 b$ & $8.87 b$ & $11.60 \mathrm{~b}$ & $8.08 \mathrm{~b}$ & $2.02 \mathrm{~b}$ \\
\hline & 60 & $105.00 \mathrm{a}$ & $12.70 \mathrm{a}$ & $14.30 \mathrm{a}$ & $22.00 \mathrm{a}$ & $5.40 \mathrm{a}$ \\
\hline \multirow{4}{*}{ Farmer2 } & 30 & $34.33 d$ & $4.10 \mathrm{~d}$ & $5.67 \mathrm{~d}$ & $0.92 d$ & $0.26 \mathrm{~d}$ \\
\hline & 40 & $65.33 c$ & $7.27 \mathrm{c}$ & $8.73 c$ & $2.97 \mathrm{c}$ & $1.08 \mathrm{c}$ \\
\hline & 50 & $84.65 b$ & $8.87 \mathrm{~b}$ & $11.52 \mathrm{~b}$ & $8.20 \mathrm{~b}$ & $2.04 \mathrm{~b}$ \\
\hline & 60 & $103.33 \mathrm{a}$ & $12.37 \mathrm{a}$ & $13.73 \mathrm{a}$ & $21.51 \mathrm{a}$ & $5.49 \mathrm{a}$ \\
\hline \multirow{6}{*}{ Local market } & 30 & $38.00 \mathrm{~d}$ & $4.35 \mathrm{~d}$ & $6.40 \mathrm{~d}$ & $0.98 \mathrm{~d}$ & $0.32 d$ \\
\hline & 40 & $66.30 c$ & $7.53 c$ & $9.37 \mathrm{c}$ & $2.56 \mathrm{c}$ & $0.78 \mathrm{c}$ \\
\hline & 50 & $85.29 b$ & $8.70 \mathrm{~b}$ & $11.65 b$ & $6.13 b$ & $1.93 \mathrm{~b}$ \\
\hline & 60 & $107.64 \mathrm{a}$ & $14.00 \mathrm{a}$ & $14.17 \mathrm{a}$ & $16.17 \mathrm{a}$ & $6.94 a$ \\
\hline & 50 & $85.29 b$ & $8.70 \mathrm{~b}$ & $11.65 b$ & $6.13 b$ & $1.93 \mathrm{~b}$ \\
\hline & 60 & $107.64 \mathrm{a}$ & $14.00 \mathrm{a}$ & $14.17 \mathrm{a}$ & $16.17 \mathrm{a}$ & $6.94 a$ \\
\hline
\end{tabular}

In a column figures having common letter(s) do not differ significantly by DMRT at $1 \%$ level of probability.

\section{Conclusion}

Seedling growth of O-9897 seed's varied significantly due to seed sources and seedling age. The seedling height, base diameter, root length, shoot dry weight and root dry weights for seedling establishment of O-9897 seed's varied significantly due to seed sources in both the condition of green house and field. The interaction of seed sources and seedling ages were highly significant and the BJRI seeds of 60 days age showed the highest plant height, base diameter, root length, shoot dry weight and root dry weights. Seeds from BJRI and BADC of the O-9897 varieties showed better performances in terms of seedling growth and dry weight compared to seeds from farmers' and local markets.

\section{Recommendation}

BJRI and BADC seed sources performed better. BJRI seeds of 60 days seedling age produced the highest shoot/stem height, base diameter, and root length, shoot dry weight and root dry weights.

\section{Author Contributions}

All the authors contributed equally. 


\section{Conflict of Interest}

The authors declare no conflict of interest exists.

\section{Acknowledgements}

Thanks to Jute Agriculture Experimental Station, Manikgonj of BJRI and Ministry of Agriculture, Bangladesh is acknowledged.

\section{References}

[1] BBS. (2015). Yearbook of Agricultural Statistics of Bangladesh. Ministry of Planning, Government of the People's Republic of Bangladesh, Dhaka, Bangladesh.

[2] Islam, M. M. and Ali, M. S. (2017). Economic Importance of Jute in Bangladesh: Production, Research Achievements and Diversification. International Journal of Economic Theory and Application, 4 (6): 45-57.

[3] Islam, M. M. and Uddin, N. (2019). Research and Development Advances of Jute Seed in Bangladesh: A Review, Haya Saudi J Life Sci., 4 (2): 52-68.

[4] Salim, M., Hannan, M. A., Sarkar, M. A. R. and Ali, M. (1998). Seed quality in late seed crop as affected by late sowing. Bangladesh J. Seed Sci. Tech. 2: 11-17.

[5] Hossain, M. A., Mannan, S. A., Sultana, K. and Khandakar, A. L. (1994). Survey on the constrains of quality jute seed at farm level. Res. Rept., Agril. Support Serv. Proj., Bangladesh Jute Res. Inst., Dhaka, Bangladesh.

[6] Islam, M. M. (2009). Jute seed technology. 1st edition. September 2009. Pub. by Md. Mahmudul Islam, 397, Middle Monipur, Mirpur, Dhaka-1216. College Gate Book Binding and Printing, Mohamadpur, Dhaka. pp. 160.

[7] M. M. Islam. (2010) Technological advances in off-season jute seed production. J. Expt. Biosci. 1 (1): 75-82.

[8] Islam, M. M.; Sarkar, M. A. R.; Ahmed, M.; Hossain, S. M. A. and Moniruzzaman, S. M. (2008) Evaluation of jute seed quality attributes and their relationship as affected by seed sources. Bangladesh J. Jute and Fib. Res. 28 (1): 31-38.

[9] Islam, M. M.; Sarkar, M. A. R.; Ahmed, M.; Moniruzzaman, S. M. and Uddin, M. N. (2009) Germination, vigour and emergence indicators of Corchorus olitorius L, seed and their relationship as influenced by seed sources. Bangladesh J. Jute and Fib. Res. 29 (1\&2): 1-8.

[10] Islam, M. M. (2016) Seed quality of two Corchorus spp. collected from different sources in Bangladesh. J. Agric. Technol. Manage. (JATM). 19 (1): 1-11.

[11] ISTA (International Seed Testing Association). (1985). International Rules for Seed Testing. 1985. Seed Sci. Tech. 13: 356-513.

[12] Gomez, A. K. and Gomez, A. A. (1984). Statistical Procedures for Agricultural Research. Second Edn. John Wiley and Sons Inc., New York. pp. 304-307.

[13] Dempsey JM (1975) Fibre crops. The university press of Florida, 15 Northwest 15th Street, Gainesville, Florida 32603. pp. 131-202.

\section{Biography}

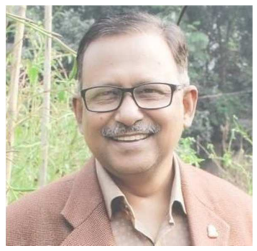

Md Mahbubul Islam (Corresponding Author) awarded $\mathrm{PhD}$ in 2008 from the Department of Agronomy of Bangladesh Agricultural University especially on Jute seed quality, plant establishment and yield. He had done his M.Sc. (Agriculture) in Agronomy and B.Sc. Agriculture (Hons.) from Bangladesh Agricultural University. $\mathrm{He}$ is working at Bangladesh Jute Research Institute (BJRI) since 1989. He is serving as Chief Scientific Officer \& Head of Agronomy Division. He has 6 books, 80 scientific papers and more than 75 popular articles published in international and national journals, newsletters etc. He visited United Kingdom, Malaysia, and India for training, seminar, workshop purpose. 